International Journal of Language Education

Volume, 5 Number, 2 2021, pp. 40-50

ISSN: 2548-8457 (Print) 2548-8465 (Online)

Doi: https://doi.org/10.26858/ijole.v5i2.18229

\title{
A Conceptual Model of Analogue Gamification to Enhance Learners' Motivation and Attitude
}

\author{
Rita Wong Mee Mee \\ Universiti Selangor, Malaysia \\ Email: ritawong@unisel.edu.my \\ Lim Seong Pek \\ Universiti Selangor, Malaysia \\ Email:limsp@unisel.edu.my \\ Wong Yee Von \\ Universiti Selangor, Malaysia \\ Email: yeevonwong@unisel.edu.my \\ Khatipah Abd Ghani \\ Universiti Selangor, Malaysia \\ Email: khatisj@unisel.edu.my
Tengku Shahrom Tengku Shahdan
Universiti Selangor, Malaysia
Email:drtengku@unisel.edu.my \\ Md Rosli Ismail \\ Open University Malaysia, Malaysia \\ Email: mdrosli@oum.edu.my \\ Yugeshineey Subba Rao \\ Universiti Selangor, Malaysia \\ Email: yugeshineey@gmail.com
}

Received: 1 December 2020

Reviewed: 3 January 2021-3 April 2021

Accepted: 3 May 2021

\begin{abstract}
The concept of gamification has spread widely in recent years supported by the development of technology, especially due to the plethora of computers and video games and game apps for other devices. Gamification is the use of game thinking and game mechanics in non-game contexts that support play to engage users in solving problems or created for teaching and learning purposes. Gamification does not mean creating games but making education more engaging and fun with play for learners, without undermining its credibility. In modern education, lessons delivery is associated with the lack of engagement and motivation of learners to
\end{abstract}


participate actively in the learning process. Teachers are increasingly faced with the problem of how to integrate technology and to impart good language learning habits at the level of primary school in Malaysia. Hence, the aim of this study is to propose a conceptual model of analogue gamification to enhance primary school learners' motivation and attitude.

Keywords: Analogue Gamification; Game-Based Learning; Serious Games; Motivation; Attitude.

\section{Introduction}

The emergence of technology has changed education from a traditional approach into a more technological oriented approach. The teaching and learning experience in the 21 st century have heavily depended on technology use (Flores, 2015). An education organisation aims to prepare individuals for future professional careers that are competent with 21 st century skills. As Mee et al. (2020) addressed, these skills as the core competencies of collaboration, digital literacy, critical thinking, and problem-solving ability. Therefore, a technological and educational revolution involving the use of games, both digital and analogue, is to be implemented into the education system to accommodate learners who are getting more indulged in the virtual world.

However, teachers faced challenges using games to make teaching and learning activities fun and engaging (Omar et al., 2020). The challenge goes beyond merely adapting to change. A frontier in educational technology emerging in the public consciousness, called 'serious gaming' challenges teachers to connect their instruction to the everyday games that learners use in their lives (McColgan, Colesante \& Andrade, 2018). As cited in Romero and Barma (2015), teachers face problems using and creating new games for teaching and learning activities. Akcaoglu and Kale (2014) mentioned that immersion impacted teachers' perceptions related to challenges, problem solving, and attitudes toward gaming and design. The use of games in teaching academic content has become a promising avenue of technology in promoting learners' motivation and engagement (McColgan et al., 2018)

Games are tools that teachers can use to improve learners' outcomes across many areas. Boyle et al. (2016) explored empirical evidence of computer games' impacts and effects of challenging games in educational settings. They found that games are successfully used for knowledge acquisition, skill acquisition, affective and perceptual goals, behaviour change, as well as cognitive and physiological outcomes. Miller and Robertson (2011) added that games in classrooms increased communication skills, resourcefulness and adaptability. However, Gerber and Price (2013) and Hsu et al. (2013) indicated that many teachers are unaware of the potential learners learning opportunities that games can provide.

The use of games focuses on the fun element and sharpens language skills (Quy, 2019). Yeh and Lin (2018) suggested that achieving mastery goals and performance goals is crucial to enhance self-efficacy and gain mastery experience in creativity. The attitude of learners who play games had shown aggressiveness but with a high competency level. Motivations in gaming involve curiosity, challenge, sense of dominance, competition, social communication, diversity, exhilaration effect, providing oneiric environments, relaxation, avoiding stress, being able to start over for many times, resting, spending spare time, and escaping from the real-life (Pala et al., 2011).

The game design experience positively influenced the participants' attitudes, self-efficacy, and perceptions regarding the use of games in the classroom. They realised that games help learners develop higher-order thinking skills and 21st century skills beyond making learning fun and engaging (An \& Cao, 2017). Considering the importance of using games in education, this 
article proposes a conceptual model of analogue gamification to enhance primary school learners' motivation and attitude.

\section{Literature review}

According to Zirawaga, Olusanya and Maduku (2017), gaming in education is interference with learning. They added that games' role in education is to increase learners' motivation and engagement, enhance visual skills, improve learners' interaction and collaboration abilities with their peers, and apply gaming values in a real-world situation. Hence, the teachers' role is to build fun learning opportunities for meaning making and engage learners in the language classroom. Koh et al. (2012) stated that teachers show positivity in adopting games to encourage teaching and learning participation.

\section{Gamification}

Gamification is defined as taking game-elements such as point scoring, competition with others, rules of play and applying them to other contexts. Games are usually applied to solve problems in engagements. Research studies have found that many children use a trial-and-error strategy for games. As such, gamifying a course would greatly help learners as they would be taking advantage of games' motivational power (Sandberg, Maris \& de Geus, 2011) and applying it to education's motivational problems. The traditional design of patterns that design the games are known as game elements. Some of these elements, sometimes described as components, are seen in most of the games nowadays, including points, badges, leaderboards, progress bars/progression charts, performance graphs, quests, levels, avatars, social elements, and rewards (Mohamad, Sazali \& Salleh, 2017). All these elements have different purposes and can be adapted to any work, business or education-related environment. Flores (2015) provided a brief definition of each element in Table 1.

Table 1. Game elements and definitions (Flores, 2015)

\begin{tabular}{|l|l|}
\hline Elements & Definitions \\
\hline Points & Numeric accumulation is based on certain activities. \\
\hline Badges & $\begin{array}{l}\text { Visual representation of achievements for the use } \\
\text { shown online. }\end{array}$ \\
\hline Leaderboards & How the players are ranked based on success. \\
\hline Progress bars/Progression & Shows the status of a player. \\
\hline Performance graph & Shows player performance. \\
\hline Quests & Some of the tasks players have to fulfil in a game. \\
\hline Levels & A section or part of the game. \\
\hline Avatars & Visual representation of a player or alter ego. \\
\hline Social elements & Relationships with another user through the game. \\
\hline Rewards/Reward system & System to motivate players that accomplish a quest. \\
\hline
\end{tabular}

\section{Game-Based Learning}

Game-based learning is defined as an approach to teaching (Sanchez, 2019). Teachers' role is to design the context for learners in exploring the relevant aspects of games introduced (Licorish et al., 2018). Game-based learning encourages learners' participation in learning while playing and makes the learning process more interesting by adding more entertainment. Yadav and Oyelere (2020) stated that game-based learning also improves cognitive development and improves learners' learning motivation as both games and courses are combined. Although game-based 
learning is being used to review and reinforce, through constant advancement of this field, it has even allowed it to be used for prior learning of complicated subjects (Abdul Jabbar \& Felicia, 2015).

\section{Serious Game}

Serious games are created for a primary purpose of education other than pure entertainment. They have an explicit and carefully thought-out educational purpose in teachinglearning that are not intended to be played merely for fun (Laamarti, Eid \& El Saddik, 2014). Serious games have been proven to improve cognitive abilities and affect a pleasant mood in general learning. Players of serious games have reported increased players' overall pleasant mood and happiness level and improved their cognitive abilities (Zhonggen, (2019). Although no significant findings supported the change in mood, Wronowski et al. (2020) found that serious games affect learners' attitudes compared to traditional paper-based learning. Such serious games could provide a more flexible learning type for learners as they could choose a time and place that feels convenient for them to learn in (Garneli, Giannakos \& Chorianopoulos, (2017).

\section{Research method}

Distinctions are needed to be made within every type of implementation of games within the educational system to differentiate its viability, positive and negative reinforcements and their effectiveness to recognise which type of implementation is best. A comparative analysis table (Table 2) distinguishes the prominent differences between these types of implementations.

A short analysis of past research to explore a comparative analysis of the implementation of games within the educational system was conducted. Five simple steps as proposed by Mohamad, Salam and Bakar (2017). Step 1 - General Database Search: A survey of the literature was conducted to explore the existing articles to compare the three approaches in teaching and learning to enhance student attitude and motivation. A total of 165 articles were found through a deep search of the academic literature in the ERIC database. The terms gamification, game-based and serious games were used to search all publications. Step 2 - Focus Search: In narrowing down the search, articles from 2017 to 2021 were collected, which found 138 articles. Step 3 - Additional Search: In order to gain more details related to this study, the use of descriptors (Student Attitude and Student Motivation) was selected. A total of 12 articles were depicted. Step 4 - Analysis: After complete reviewing the articles, all the relevant in confirming the work from Al-Azawi, Al-Faliti, and Al-Blushi (2016) as shown in Table 2 and Step 5- Future Study: For further study, a detailed Systematic Literature Review analysis of past research will be conducted through more comprehensive databases.

Table 2. Comparative Analysis Table (Adapted Al-Azawi et al., 2016)

\begin{tabular}{|l|l|l|l|}
\hline Comparison & Game-based Learning & \multicolumn{1}{c|}{ Serious Games } & \multicolumn{1}{c|}{ Gamification } \\
\hline Concept & $\begin{array}{l}\text { Games are used to } \\
\text { improve the learning } \\
\text { experience. }\end{array}$ & $\begin{array}{l}\text { Games explicitly } \\
\text { designed help learners } \\
\text { understand a particular } \\
\text { subject, e.g., expanded } \\
\text { concept, historical events } \\
\text { and culture, and }\end{array}$ & $\begin{array}{l}\text { The implementation of } \\
\text { games (badges, } \\
\text { milestones, } \\
\text { achievements, \& etc.) } \\
\text { into a non-game structure } \\
\text { to reward learners for } \\
\text { certain behaviours. }\end{array}$ \\
\hline
\end{tabular}




\begin{tabular}{|c|c|c|c|}
\hline & & $\begin{array}{l}\text { reinforcing } \\
\text { developments. }\end{array}$ & \\
\hline Objective & $\begin{array}{l}\text { Achievements in the } \\
\text { game itself directly } \\
\text { motivate the learners. }\end{array}$ & $\begin{array}{l}\text { The teaching of basics } \\
\text { and particularities of a } \\
\text { subject. }\end{array}$ & $\begin{array}{l}\text { Gain motivation from the } \\
\text { implemented elements. }\end{array}$ \\
\hline Challenge & $\begin{array}{l}\text { Finding materials to } \\
\text { adapt to the teaching } \\
\text { and learning } \\
\text { experience. }\end{array}$ & $\begin{array}{l}\text { - Learners might find } \\
\text { the materials to be } \\
\text { unengaging. }\end{array}$ & $\begin{array}{l}\text { - Limited } \\
\text { implementation of } \\
\text { elements. } \\
\text { - New challenges are } \\
\text { hard to provide. }\end{array}$ \\
\hline Character & $\begin{array}{l}\text { Learners are given } \\
\text { characters that fit the } \\
\text { situations of the } \\
\text { materials. }\end{array}$ & $\begin{array}{l}\text { Mostly narrative, } \\
\text { Characters are tied to the } \\
\text { subject. }\end{array}$ & $\begin{array}{l}\text { Learner as the } \\
\text { avatar/player. }\end{array}$ \\
\hline Techniques & $\begin{array}{ll}\text { - } & \text { Motivation } \\
\text { - } & \text { Practice } \\
\text { - } & \text { Story } \\
\text { - } & \text { Emotional } \\
\text { - } & \text { investments } \\
\text { - } & \text { Chals and } \\
& \text { Challenges }\end{array}$ & $\begin{array}{ll}\text { - } & \text { Learning and } \\
\text { Problem Solving } \\
\text { - } & \text { Adaptation of } \\
& \text { Materials } \\
\text { - } & \text { Interactions } \\
\text { - } & \text { Goals and Pleasure }\end{array}$ & $\begin{array}{ll}\text { - } & \text { Milestone } \\
\text { - } & \text { Progression } \\
\text { - } & \text { Badges } \\
\text { - } & \text { Peer Competition }\end{array}$ \\
\hline Benefits & $\begin{array}{l}\text { - Can increase a } \\
\text { learner's memory } \\
\text { capacity } \\
\text { - Computer Fluency } \\
\text { - } \quad \text { Improve strategic } \\
\text { thinking } \\
\text { - Develops hand-eye } \\
\text { coordination } \\
\text { - Develops real-life } \\
\text { skills } \\
\text { (communication } \\
\text { skills, map reading, } \\
\text { etc.) }\end{array}$ & $\begin{array}{l}\text { - } \text { Develop social skills } \\
\text { - Improves motor } \\
\text { skills } \\
\text { - } \text { Improves focus and } \\
\text { memory } \\
\text { - Induce creativity }\end{array}$ & $\begin{array}{l}\text { - Improves learning } \\
\text { experience. } \\
\text { Improves learning } \\
\text { situations. } \\
\text { - Feedbacks are } \\
\text { instant. } \\
\text { - Can be applied to the } \\
\text { majority of learning } \\
\text { needs and situations. }\end{array}$ \\
\hline Rewards & $\begin{array}{l}\text { Essential rewards, losing } \\
\text { may not be possible. }\end{array}$ & $\begin{array}{l}\text { Points are scored and } \\
\text { graded. }\end{array}$ & $\begin{array}{l}\text { Reach new milestones } \\
\text { and gain experiences and } \\
\text { rewards. }\end{array}$ \\
\hline Levels/Cost & Hard/Expensive & $\begin{array}{l}\text { Various Difficulties/ } \\
\text { Expensive }\end{array}$ & Easy/Cheap \\
\hline Content & $\begin{array}{l}\text { Contents are adapted into } \\
\text { the game rather than the } \\
\text { other way around. }\end{array}$ & $\begin{array}{l}\text { Structured activity, with } \\
\text { the context of a story, } \\
\text { competition is possible. }\end{array}$ & $\begin{array}{l}\text { Elements are } \\
\text { implemented into the }\end{array}$ \\
\hline
\end{tabular}




\begin{tabular}{|l|l|l|l|}
\hline & & & $\begin{array}{l}\text { Learning Management } \\
\text { System (LMS) }\end{array}$ \\
\hline Examples & $\begin{array}{l}\text { SimCity, World of } \\
\text { Warcraft, Portal }\end{array}$ & $\begin{array}{l}\text { Scribblenauts, Code } \\
\text { Spells. Dragon Box }\end{array}$ & Classcraft, Lifesaver \\
\hline
\end{tabular}

Different forms of games are widely used in education. Designing appropriate games can increase learners' acceptance of learning content (Al Fatta, Maksom \& Zakaria, 2018). As seen in Table 1, gamification is different from game-based learning as it takes the entire learning process by turning it into a game (Al-Azawi et al., 2016). A study conducted by Kapp (2014) stated gamebased learning employs a real game in delivering skill and knowledge involving a specific start, gameplay and ending state. Game-based learning offers different kinds of educational content in various settings to engage learners in an educational setting.

On the contrary, serious games exclude fun, entertainment and enjoyment as their primary focus. Laamarti et al. (2014) stated that an essential component of a serious game is users' experience exposed to a designated environment that delivered unique content. A serious game is primarily intended to teach or train a subject that separates the game's learning contents from fun mechanics (Silva, 2020). Besides, gamification, however, employs various game elements. The learners do not interact with the whole game from the beginning, but they could get awarded by utilising game elements when they complete the task, cope with challenges, and get points (Mee et al. 2020).

\section{Proposed Conceptual Model}

A proposed conceptual model of analogue gamification to enhance primary school learners' motivation and attitude as shown in Figure 1.

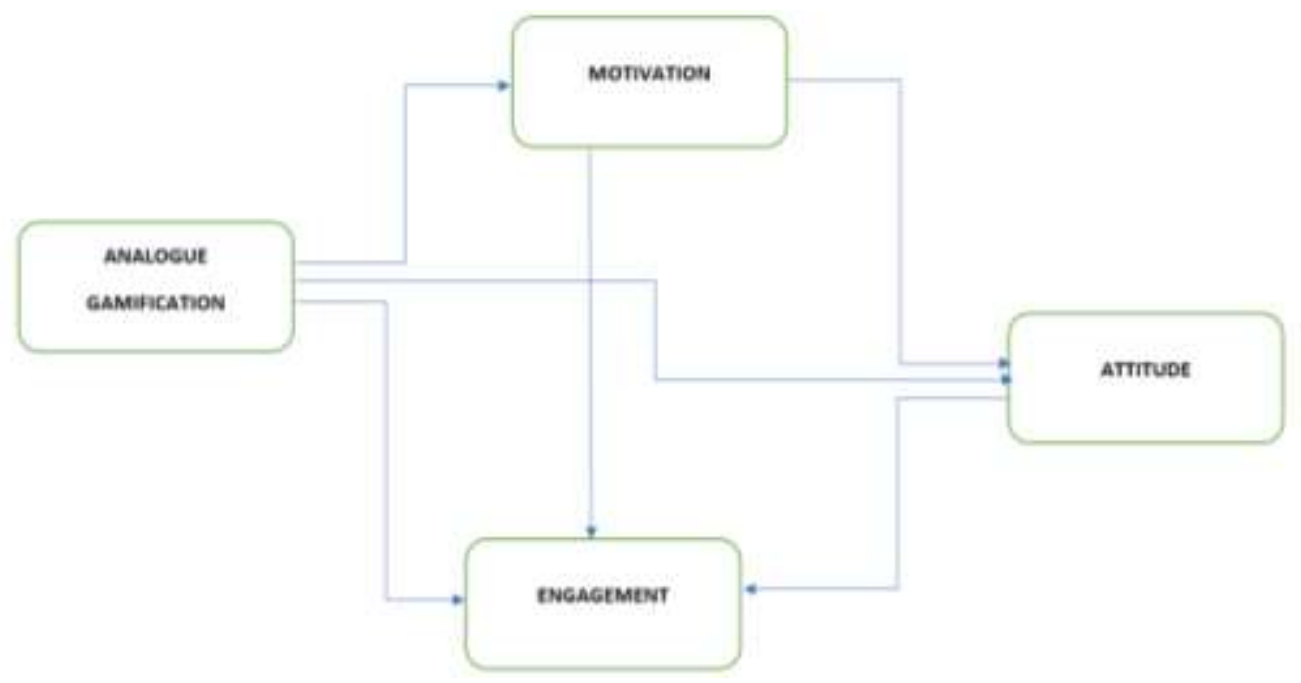

Figure 1. The Proposed Conceptual Model

\section{Analogue Gamification}

The role of technologies is the most crucial part of helping language teachers conduct practical teaching-learning activities. However, teachers face problems in conducting games through digital form inside the classroom. Hence, this study focused on analogue games as an 
emerging cultural phenomenon at the present moment due to their explicit relationality to the digital systems. As Looney (2011) stated, to the like of digital systems, analogue systems provide an interface, software and processing power in creating a gameplay experience. Analogue games involve skill, knowledge, or chance where players follow fixed rules (Zirawaga et al., 2017) as similar to the digital version.

Analogue games have great positive potential and excellent entertainment value to its users (Johnson \& Luo, 2019) as a support tool to complement traditional teaching in improving learning experiences. Education today is no longer to provide information to learners, but rather to prepare learners to become active 21st century critical thinkers (Ratnaningsih, 2016). Zirawaga et al. (2017) stated that teachers had used analogue games to promote learning for many years in the world of education. With the integration of gamified analogue games, this study was conducted to determine the significant effect of analogue gamification on learners' motivation and attitude among primary school learners.

\section{Motivation}

There are two main types of motivation acknowledged - intrinsic motivation and extrinsic motivation. Intrinsic motivation is the internal motivational that drive to behave in specific ways for the sake of the behaviour itself and the internal reward provided. On the other hand, extrinsic motivation is the pursuit of behaviour for some other extrinsic reason, conditional to the behaviour's conduct (Broer \& Poeppelbuss, 2013). Based on Figure 1, Deterding et al. (2011) indicated that some gamification elements directly influence extrinsic motivation, primarily through the use of stimuli and extrinsic rewards. Reward-based gamification solely relies on the external provision of rewards to influence behaviour. Thus, behavioural change through this method tends to be conditional on extrinsic rewards' continuous provision unless the behavioural change's motivation is internalised (Bogost, 2015; Nicholson, 2015). Besides, if there is a lack of intrinsic motivation for a specific behaviour and the behaviour does not require a tremendous amount of mental effort; reward-based gamification is expected to be motivationally sufficient. Thus, reward-based gamification is useful for quick, short-termed behavioural change that lasts for as long as the rewards are available (Jones et al., 2014).

\section{Attitude}

Motivation is also linked to positive attitude outcomes, such as increased effort, persistence and enhanced performance (Buckley \& Doyle, 2016). Both motivation and positive attitude need to coexist in order to achieve a successful language learning experience (Ming, Ling \& Jaafar, 2011). This ideal relationship is further highlighted that learners with positive attitudes and a high level of motivation will be more successful than their counterparts (Omar et al., 2020). According to Pek and Mee (2015), highly motivated learners with a positive attitude tend to generate activity engagement opportunities. On the other hand, learners who shown low motivation and attitude tend to lose interest in learning since attitudes produce an obstacle in the learning process. Thus, it is suggested that attitude directly affects learners' performance in second language acquisition (Getie, 2020). Therefore, gamified elements found in analogue gamification act as external stimuli meant to produce desirable learners' behaviour, leading to good or bad cognitive associations between motivational stimuli and learner behaviour. 


\section{Engagement}

Engagement is a directional expression of motivation. This directional expression offers a behavioural clue as to what individuals are interested in and have the motivation to engage with (Rigby, 2015). Icard (2014) stated the use of games in class provides learners with an exciting learning experience. In addition, Reeve (2012) stated that engagement is the degree to which learners exhibit their active participation, attentiveness, and enthusiasm when they become involved in learning, contributing to satisfying learning performance. Hence, analogue gamification implemented in this study produces educational purposes as a strategy to foster learners' engagement in different content areas, including language learning. Games can create a better learning environment with stimulating learning and promote learner's engagement. Thus, gamified activity has also been conceptualised as a process of enhancing users' value creation through the employment of affordances for a gameful experience (Huotari \& Hamari, 2016).

\section{Conclusion}

The proposed conceptual model shows the significant components that create a useful model for learning through analogue gamification. Every component inside this model plays a role in ensuring that learning would occur while playing the game. This study proposes a conceptual model of analogue gamification for 21 st century language learning skills among primary school learners over Selangor, Malaysia. In the current time, there is a need for language teachers in looking for new strategies and teaching techniques in making the classroom fun and interesting for their learners (Pek \& Mee, 2015). Therefore, teachers need to able to design gamified activities to capture young learners' interest. The collaboration of gamification in education is a milestone for the effective implementation of active learning. Unlike training, games possess a vital competitive element. The learning process's focus should be rather towards developing skills for collaboration and teamwork and responsibility for the group's performance instead of competition between learners.

Declaration of conflicting interest

The authors state that there is no conflict of interest concerning the publication of this article.

Funding acknowledgement

We would like to thank the Malaysian Ministry of Higher Education for funding this study.

This work was supported by Universiti Selangor (UNISEL) under Grant Nos. FRGS/1/2019/SSI09/UNISEL/03/3.

\section{References}

Abdul Jabbar, A. I., \& Felicia, P. (2015). Gameplay engagement and learning in game-based learning: A systematic review. Review of educational research, 85(4), 740-779.

Akcaoglu, M., \& Kale, U. (2016). Teaching to teach (with) game design: Game design and learning workshops for preservice teachers. Contemporary Issues in Technology and Teacher Education, 16(1), 60-81.

Al-Azawi, R., Al-Faliti, F., \& Al-Blushi, M. (2016). Educational gamification vs. game based learning: Comparative study. International Journal of Innovation, Management and Technology, 7(4), 132-136. 
Al Fatta, H., Maksom, Z., \& Zakaria, M. H. (2018). Game-based Learning and Gamification: Searching for Definitions. International Journal of Simulation: Systems, Science and Technology.

An, Y. J., \& Cao, L. (2017). The effects of game design experience on teachers' attitudes and perceptions regarding the use of digital games in the classroom. TechTrends, 61(2), 162-170.

Bogost, I. (2015). Why gamification is bullshit. The gameful world: Approaches, issues, applications, 65.

Boyle, E. A., Hainey, T., Connolly, T. M., Gray, G., Earp, J., Ott, M., ... \& Pereira, J. (2016). An update to the systematic literature review of empirical evidence of the impacts and outcomes of computer games and serious games. Computers \& Education, 94, 178-192.

Broer, J., \& Pöppelbuß, J. (2013). Gamification-a New Phenomenon in Information Systems Research?.

Buckley, P., \& Doyle, E. (2016). Gamification and student motivation. Interactive learning environments, 24(6), 1162-1175.

Deterding, S., Sicart, M., Nacke, L., O'Hara, K., \& Dixon, D. (2011). Gamification. using gamedesign elements in non-gaming contexts. CHI'11 extended abstracts on human factors in computing systems, 2425-2428.

Flores, J. F. F. (2015). Using gamification to enhance second language learning. Digital Education Review, (27), 32-54.

Garneli, V., Giannakos, M., \& Chorianopoulos, K. (2017). Serious games as a malleable learning medium: The effects of narrative, gameplay, and making on students' performance and attitudes. British Journal of Educational Technology, 48(3), 842-859.

Gerber, H. R., \& Price, D. P. (2013). Fighting baddies and collecting bananas: Teachers' perceptions of games-based literacy learning. Educational Media International, 50(1), 5162.

Getie, A. S. (2020). Factors affecting the attitudes of students towards learning English as a foreign language. Cogent Education, 7(1), 1738184.

Hsu, C. Y., Liang, J. C., Chai, C. S., \& Tsai, C. C. (2013). Exploring preschool teachers' technological pedagogical content knowledge of educational games. Journal of Educational Computing Research, 49(4), 461-479.

Huotari, K., \& Hamari, J. (2017). A definition for gamification: anchoring gamification in the service marketing literature. Electronic Markets, 27(1), 21-31.

Icard, S. B. (2014). Educational technology best practices. International Journal of instructional technology and distance learning, 11(3), 37-41.

Johnson, M. R., \& Luo, Y. (2019). Gaming-value and culture-value: Understanding how players account for video game purchases. Convergence, 25(5-6), 868-883.

Jones, B. A., Madden, G. J., \& Wengreen, H. J. (2014). The FIT Game: preliminary evaluation of a gamification approach to increasing fruit and vegetable consumption in school. Preventive medicine, 68, 76-79.

Kapp, K. (2014). GAMIFICATION: Separating Fact From Fiction. Chief Learning Officer, 13(3), 45-52.

Koh, E., Kin, Y. G., Wadhwa, B., \& Lim, J. (2012). Teacher perceptions of games in Singapore schools. Simulation \& Gaming, 43(1), 51-66.

Laamarti, F., Eid, M., \& El Saddik, A. (2014). An overview of serious games. International Journal of Computer Games Technology, 2014. 
Licorish, S. A., Owen, H. E., Daniel, B., \& George, J. L. (2018). Students' perception of Kahoot!'s influence on teaching and learning. Research and Practice in Technology Enhanced Learning, 13(1), 9.

Looney, J. (2011). Developing High-Quality Teachers: teacher evaluation for improvement. European Journal of Education, 46(4), 440-455.

McColgan, M., Colesante, R., \& Andrade, A. (2018). Pre-service teachers learn to teach with serious games. Journal of STEM Education, 19(2).

Mee, R. W. M., Shahdan, T. S. T., Ismail, M. R., Ghani, K. A., Pek, L. S., Von, W. Y., Woo, A., \& Rao, Y.S. (2020). Role of gamification in classroom teaching: Pre-service teachers' view. International Journal of Evaluation and Research in Education, 9(3), 684-690.

Miller, D. J., \& Robertson, D. P. (2011). Educational benefits of using game consoles in a primary classroom: A randomised controlled trial. British Journal of Educational Technology, 42(5), 850-864.

Ming, T. S., Ling, T. S., \& Jaafar, N. M. (2011). Attitudes and motivation of Malaysian secondary students towards learning English as a second language: A case study. 3L: Language, Linguistics, Literature ${ }^{\circledR}, 17(1)$.

Mohamad, S. N. M., Salam, S., \& Bakar, N. (2017). An analysis of gamification elements in online learning to enhance learning engagement. Proceedings of the 6th International Conference on Computing \& Informatics, 452-460.

Mohamad, S. N. M., Sazali, N. S. S., \& Salleh, M. A. M. (2018). Gamification approach in education to increase learning engagement. Int. J. Humanit. Arts Soc. Sci, 4(1), 22-32.

Nicholson, S. (2015). A recipe for meaningful gamification. Gamification in education and business, 1-20.

Omar, S. F., Nawi, H. S. A., Shahdan, T. S. T., Mee, R. W. M., Pek, L. S., \& Yob, F. S. C. (2020). Interactive language learning activities for learners' communicative ability. International Journal of Evaluation and Research in Education, 9(4), 1010-1016.

Pala, A., Akyıldız, M., \& Bağc1, C. (2011). Academic procrastination behaviour of pre-service teachers' of Celal Bayar University. Procedia-Social and Behavioral Sciences, 29, 14181425.

Pek, L. S., \& Mee, R. W. M. (2015). Selfie: Engaging Life Experiences into Writing. Malaysian Journal of Distance Education, 17(2).

Quy, P. H. P. (2019). Cooperative Game-Playing in the EFL Classroom. English Teaching Forum, 57(3), 14-23.

Ratnaningsih, N. (2018). The Analysis of Mathematical Creative Thinking Skills and Self-Efficacy of High Students Built Through Implementation of Problem Based Learning and Discovery Learning. JPMI (Jurnal Pendidikan Matematika Indonesia), 2(2), 42-45.

Reeve, J. (2012). A self-determination theory perspective on student engagement. Handbook of research on student engagement, 149-172.

Rigby, C. S. (2015). Gamification and motivation. The gameful world: Approaches, issues, applications, 113-138.

Romero, M., \& Barma, S. (2015). Teaching pre-service teachers to integrate Serious Games in the primary education curriculum. International Journal of Serious Games, 2(1).

Sanchez E. (2019). Game-Based Learning. In: Tatnall A. (eds) Encyclopedia of Education and Information Technologies. Springer, Cham.

Sandberg, J., Maris, M., \& De Geus, K. (2011). Mobile English learning: An evidence-based study with fifth graders. Computers \& Education, 57(1), 1334-1347. 
Silva, F. G. (2020). Practical Methodology for the Design of Educational Serious Games. Information, 11(1), 14.

Wronowski, M., Urick, A., Wilson, A. S., Thompson, W., Thomas, D., Wilson, S., ... \& Ralston, R. (2020). Effect of a serious educational game on academic and affective outcomes for statistics instruction. Journal of Educational Computing Research, 57(8), 2053-2084.

Yadav, A. K., \& Oyelere, S. S. (2020). Contextualized mobile game-based learning application for computing education. Education and Information Technologies, 1-24.

Yeh, Y. C., \& Lin, C. S. (2018). Achievement goals influence mastery experience via two paths in digital creativity games among elementary school students. Journal of Computer Assisted Learning, 34(3), 223-232.

Zhonggen, Y. (2019). A meta-analysis of use of serious games in education over a decade. International Journal of Computer Games Technology, 1-8.

Zirawaga, V. S., Olusanya, A. I., \& Maduku, T. (2017). Gaming in Education: Using Games as a Support Tool to Teach History. Journal of Education and Practice, 8(15), 55-64. 